COST Action FP1202

"Strengthening conservation: a key issue for adaptation of marginal/peripheral populations of forest trees to climate change in Europe (MaP-FGR)"

Guest Editors: Fulvio Ducci, Kevin Donnelly

\title{
Regeneration dynamics in the laurel forest: changes in species richness and composition
}

\author{
José Ramón Arévalo ${ }^{(1)}$, \\ Lea de Nascimento ${ }^{(1)}$, \\ Silvia Fernández-Lugo ${ }^{(1)}$, \\ Javier Méndez ${ }^{(1)}$, \\ Guacimara González-Delgado ${ }^{(1)}$, \\ Eduardo Balguerías ${ }^{(1)}$, \\ Eduardo Pereira Cabral Gomes (2), \\ José María Fernández-Palacios ${ }^{(1)}$
}

\begin{abstract}
The recovery and survival of the Macaronesian laurel forest depends on its regeneration strategies. After years of long-term monitoring, both sexual and asexual regeneration appear to be equally important. However, the mechanisms for each are just beginning to be understood. In order to contribute to the understanding of the laurel forest sexual regeneration, we analyzed the species composition of the seedling bank every two weeks over three years in the laurel forest of Anaga (Tenerife, Canary Islands). We compared the species compositions of the seedling bank with the canopy, and analyzed changes in their diversity over this period in different forest stands. We found that species diversity (evenness) is different among plots regardless of the stand. In some cases, plot diversity remained constant over time, while others showed some variations, which were little related to climatic conditions (temperature and precipitation). We also found no relationship between the seedling bank and canopy composition, with shade-intolerant species being more abundant in the former. Although climatic conditions remained constant during the period and other environmental conditions did not vary either, some changes were found in the seedling bank species composition. These were related to the increased degree of conservation of the laurel forest of Anaga (by closing unpaved roads, limiting access, and the abandonment of agriculture) that had negatively affected the density of shade-intolerant species. We suggest that such conservation measures should be maintained and extended to other areas where agriculture has been recently abandoned to allow the potential establishment of laurel forest and late successional species.
\end{abstract}

Keywords: Conservation, Evenness, Regeneration, Seedling Bank, Species Composition

\section{Introduction}

The structural and species composition of forests depend considerably on the reproductive abilities of the dominant tree species that make up its canopy. Indeed, seed dispersal and seedling establishment are important constraints and may represent a major bottleneck in plant population dynamics (García 2001, Rey \& Alcántara 2000). Thus, processes occurring at the seedling level, the most vulnerable stage in the life of a plant species, could have a major impact on the natural regeneration of forests (Kitajima 2007, Peterken 1996).

Understanding natural regeneration is of paramount importance to examine the build-up of future forest structure and composition (Ceccon et al. 2006, Tesfaye et al. 2002). The processes involved in tree sexual regeneration can be influenced by many factors, such as variations in seed dispersal intervals, seed quality, wind direction and speed, slope gradients and aspects and soil moisture availability (Vieira \& Scariot 2006). In addition, intra- and interspecies competition for water, nutrients, light, and space are also important factors in the regeneration and growth of species (Smith et al. 1997). However, regeneration dynamics are a heterogenic aspect of forests, and environmental conditions significantly affect the survival rate within the seedling bank as well as species composition under similar canopy composition (Fernández-Lugo et al. 2015). Furthermore, natural regeneration can also be affected by human disturbances (deforestation, soil degradation, grazing and fire) and changing species composition of the forest stands (Shono et al. 2007, Arévalo \& Fernández-Palacios 2007).

The Macaronesian laurel forest is a unique relic ecosystem hosting the highest levels of biodiversity within Europe. It is currently distributed in the archipelagos of Azores, Madeira and the Canary Islands. In the Canary Islands, the laurel forest covers an area of about 10,000 ha, representing only $12 \%$ of its original extension before humans arrived on these islands (Del Arco et al. 2010). Since the arrival of Europeans $\left(15^{\text {th }}\right.$ century), the laurel forest on Tenerife (Canary Islands) has been extensively exploited (Parsons 1981) and currently, only 
$10 \%$ of the forest remains in unexploited areas. These areas are well preserved and only small human disturbances have occurred in recent years, as protection of this laurel forest was initiated forty years ago. No data are available about the forest age, but we assume that this evergreen forest is at least a few generations old. This assumption is supported by the lack of reports on government exploitation in this area in the last century (Arévalo \& Fernández-Palacios 1998). In addition, aerial pictures taken through time show a similar forest (in terms of extension and structure) without noticeable disturbances. In the research literature, the laurel forest composition has been well described but poorly analyzed in terms of its dynamic processes, a very common situation for montane cloud forests (Fernández-Palacios \& Arévalo 1998, Hamilton et al. 1995).

This paper focuses on the sexual regeneration dynamics of the laurel forest in Tenerife, Canary Islands. In order to contribute to the understanding of the laurel forest's dynamics and diversity, we analysed three forest stands over three years in which seedling bank dynamics were monitored every two weeks. We wanted to test the following hypotheses: (i) laurel forest sexual regeneration is consistent with the canopy composition, thus we are able to explain forest diversity through sexual regeneration; and (ii) species composition and dynamics in the seedling bank remain constant throughout the year.

This paper provides useful information for the development of restoration and af- forestation plans in the laurel forest of the Canary Islands and to offer guidance for forest management in order to restore natural forests.

\section{Material and methods}

\section{Study site}

The study was undertaken in the Anaga Rural Park, which is located in the northeastern corner of the island of Tenerife, $\mathrm{Ca}$ nary Islands $\left(28^{\circ} 19^{\prime} \mathrm{N}, 16^{\circ} 34^{\prime} \mathrm{W}\right.$ - Fig. 1). The park includes a 7-8 million-year-old basaltic massif (Ancochea et al. 1990) that covers a total of 14,224 ha, spans an altitudinal range from sea level to $1024 \mathrm{~m}$ a.s.l (Cruz de Taborno) and represents $7 \%$ of Tenerife's total surface area. The park is characterized by a complex topography dominated by ravines, valleys and cliffs and a central ridge running from northeast to northwest, which results in well-defined northern and southern slopes (Morales \& Pérez 2000). The soils have been classified in the order Entisol, suborder Orthens (Fernández Caldas et al. 1985). The climate is influenced by the trade winds, which produce a "sea of clouds" on the windward slopes and wetter conditions on the northern than on the southern slopes. The annual precipitation of the park reaches 900 $\mathrm{mm}$, but can be twice this amount if fog drip is taken into account (Kämmer 1974). The mean annual temperature is close to 15 ${ }^{\circ} \mathrm{C}$ with minimal annual and daily fluctuations and no frost events.

The Park encompasses the best preserved laurel forest remnants and the most biodiverse area of the island. In the Anaga laurel forest, there is a total of 19 tree species (Santos 1990), with Erica arborea, E. platycodon ssp. platycodon, llex canariensis, Laurus novocanariensis, Morella faya, Prunus lusitanica ssp. hixa, and Viburnum rigidum being the dominant species. The forest understory is composed of seedlings, saplings and suckers of tree species, and ferns (such as Diplazium caudatum, Dryopteris spp., Woodwardia radicans), with endemic shrubs and forbs (Canarina canariensis, Sideritis spp., Pericallis spp., Geranium reuteri, Isoplexis canariensis) being present in the most open areas (Fernández-Palacios 2009). Nomenclature of plant species follows Acebes et al. (2010).

\section{Sampling design}

In the year 2000, we selected three study sites, representing well-preserved laurel forest stands: "El Moquinal" (plots A, B, C) and "Barranco de los Núñez" (plots D, E, F) on the windward slopes (685-820 $\mathrm{m}$ a.s.l.), and "Monte de Aguirre" (plots G, H, J) on the leeward slopes (630-920 $\mathrm{m}$ a.s.l.) of the Anaga Rural Park (Fig. 1). At each station, three randomly located permanent plots $(10 \times 10 \mathrm{~m})$ were established, marked with iron bars at the corners, and these points were geo-referenced with fixed UTM coordinates to record data with a high degree of precision and minimal amount of sampling error. In summary, there were three leeward plots and six windward ones (Tab. 1).

Starting in winter 2000, within each plot emerging seedlings were permanently
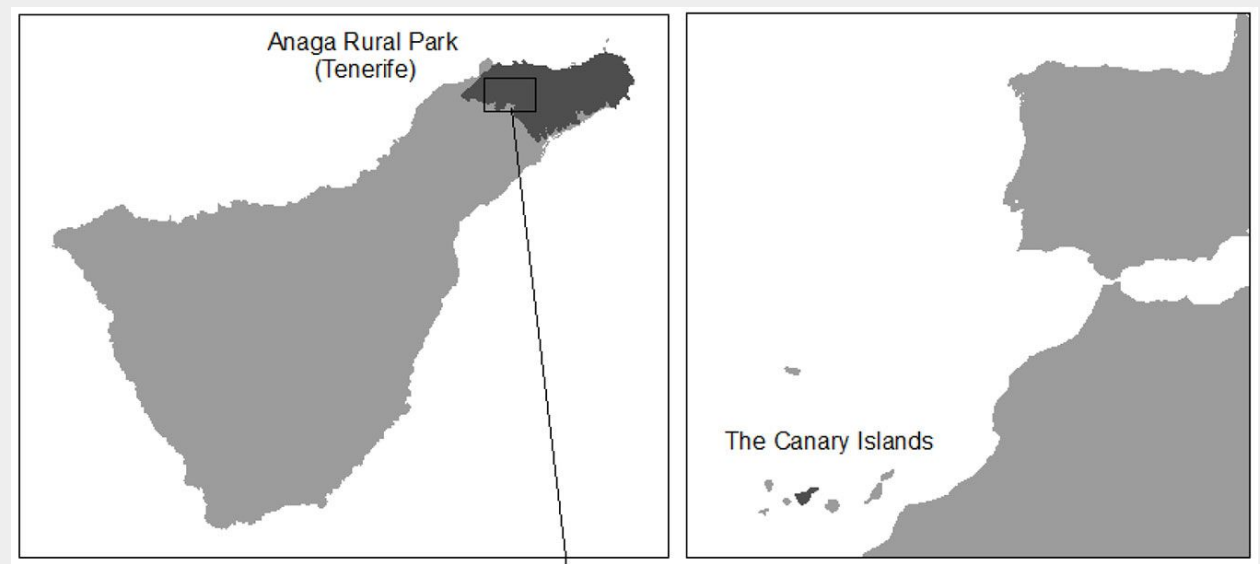

Fig. 1 - Location of Anaga Rural Park in Tenerife and laurel forest stands of El Moquinal and Barranco de los Núñez (windward) and Monte de Aguirre (leeward).

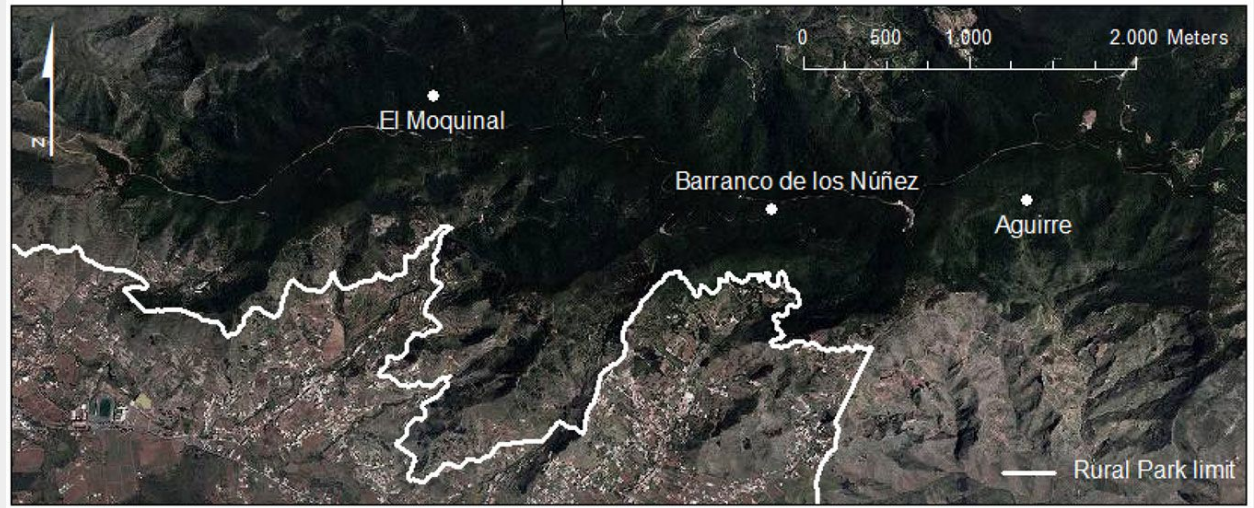


Tab. 1 - General characteristics of the studied plots in the laurel forest of Anaga (Tenerife). Plots A-C were located at the "El Moquinal" sampling site; D-F at "Barranco de los Núñez" and G-I at "Monte de Aguirre".

\begin{tabular}{|c|c|c|c|c|c|c|c|c|c|}
\hline Plot & $\begin{array}{l}\text { Altitude } \\
\text { (m a.s.l.) }\end{array}$ & $\begin{array}{l}\text { Slope } \\
\left({ }^{\circ}\right)\end{array}$ & Aspect & $\begin{array}{l}\text { Tree density } \\
\qquad\left(\mathrm{n} \mathrm{ha}^{-1}\right)\end{array}$ & $\begin{array}{l}\text { Basal Area } \\
\left(\mathrm{m}^{2} \mathrm{ha}^{-1}\right)\end{array}$ & $\begin{array}{l}\text { Canopy } \\
\text { cover (\%) }\end{array}$ & $\begin{array}{c}\text { Light } \\
\text { incidence } \\
\text { (lux) }\end{array}$ & $\begin{array}{l}\text { Regeneration } \\
\text { richness }\end{array}$ & $\begin{array}{l}\text { Canopy } \\
\text { richness }\end{array}$ \\
\hline A & 685 & 18 & NW $\left(310^{\circ}\right)$ & 1500 & 34.52 & 96 & 1.5 & 8 & 7 \\
\hline B & 790 & 12 & $W\left(260^{\circ}\right)$ & 2900 & 55.89 & 99 & 1.2 & 5 & 4 \\
\hline C & 780 & 20 & $N W\left(45^{\circ}\right)$ & 2600 & 41.95 & 98 & 2.3 & 4 & 5 \\
\hline D & 815 & 27 & $N\left(350^{\circ}\right)$ & 3600 & 58.92 & 98 & 3.0 & 7 & 7 \\
\hline $\mathrm{E}$ & 820 & 25 & $\operatorname{SW}\left(220^{\circ}\right)$ & 2900 & 36.74 & 98 & 2.8 & 6 & 4 \\
\hline $\mathrm{F}$ & 810 & 18 & $W\left(240^{\circ}\right)$ & 1300 & 50.96 & 98 & 3.5 & 7 & 5 \\
\hline G & 630 & 25 & $S\left(190^{\circ}\right)$ & 3000 & 32.98 & 96 & 4.5 & 7 & 4 \\
\hline $\mathrm{H}$ & 900 & 45 & $S\left(180^{\circ}\right)$ & 4900 & 48.32 & 96 & 12.0 & 4 & 6 \\
\hline $\mathrm{J}$ & 820 & 30 & $S\left(180^{\circ}\right)$ & 1500 & 32.02 & 96 & 3.8 & 9 & 3 \\
\hline
\end{tabular}

tagged by tying a plastic label to the stem and mapped ( $\mathrm{x}$, $\mathrm{y}$ coordinates within each plot). The seedling bank was monitored every two weeks and seedling establishment and death date were recorded. At the plot level, we also recorded the following parameters: altitude ( $m$ a.s.l.), slope (degrees), DBH (diameter at breast height in $\mathrm{cm}$ for individuals taller than $1.30 \mathrm{~m}$ with a $\mathrm{DBH}$ of at least $1 \mathrm{~cm}$ ), tree density (individuals $\mathrm{m}^{-2}$ ), seedling density (seedling $\mathrm{m}^{-2}$ ), basal area $\left(\mathrm{m}^{2}\right.$ ha $\left.{ }^{-1}\right)$, canopy height $(\mathrm{m})$ and canopy cover (\%, using a spherical densitometer); the two last parameters were measured at each plot corner and the plot centre. Additionally, we measured the percentage of light above the vegetation that reaches the ground surface. Percentage of light penetration was measured using a point quantum sensor, taking nine measurements per plot (one measure each five meters) to cope with spatial variation in light, and two measurements outside the canopy. Sampling was carried out from December 2000 to December 2003. There is a maximum variation of 4 sampled periods at the beginning and at the end of the survey, but all the plots include between 50 and 54 sampling periods.

The nearest meteorological station with complete data series is located around 3-5 $\mathrm{km}$ from the three studied sites (AnagaTaganana meteorological station), but at a lower elevation (300 $\mathrm{m}$ a.s.l.). We provide the mean, maximum and minimum temperatures for each month from 1999 to 2004, and the monthly precipitation for the same period, in order to relate possible changes in the seedling bank with changes in weather conditions in the previous years.

\section{Statistical analyses}

Environmental characteristics and stand structure of the groups of plots were analysed by the analysis of variance (ANOVA) following the same procedure. Normality of the data was checked with the ShapiroWilk test and the homoscedasticity of the data with an $F$ test $(\mathrm{p}<0.05)$. The post-hoc Tukey's test was used to test for significant differences between group means for the different variables. We looked for differences between these groups in elevation, slope, canopy cover, tree density, tree basal area and light penetration.

To measure the distribution of abundance among species in the seedling community, a basic feature of biological plant communities, we calculated the evenness index of Smith \& Wilson (1996) for each sampled period of each plot and represented it graphically in order to determine temporal changes over the study period. For these calculations, we used the seedling density of the species and each different sampling period and location.

Ordination techniques were applied to explain the community variation (Gauch 1982), and to evaluate trends over time and space (Franklin et al. 1999, Ter Braak \& Šmilauer 1998). We used Detrended Correspondence Analysis (DCA - Hill \& Gauch 1980) using the CANOCO software (Ter Braak \& Šmilauer 1998) to examine how the seedling bank species composition changed over time in each plot. We included in the analyses all the sampled peri- ods, between 49 and 53 sampled periods per plot (indicated as "Plot_" followed by the letter that identifies the plot). We also included the species composition of the canopy (indicated as "Can_" followed by the plot's letter). In order to standardize all the information, we based the analyses on the percentage of the species density. All the regeneration periods analysed per plot were represented by the centroid of all the periods sampled.

Basic statistical methods followed Zar (1984) and were implemented using the SPSS $^{\oplus}$ statistical package (SPSS Inc 1997).

\section{Results}

During the sampled period, we did not register any relevant variability for temperatures and precipitation. Only during the summer of 2004 did the average temperature increase by $2{ }^{\circ} \mathrm{C}$, while it remained practically the same in the previous 5 years (Fig. 2a). With respect to precipitation, there is one rainy period during the year,

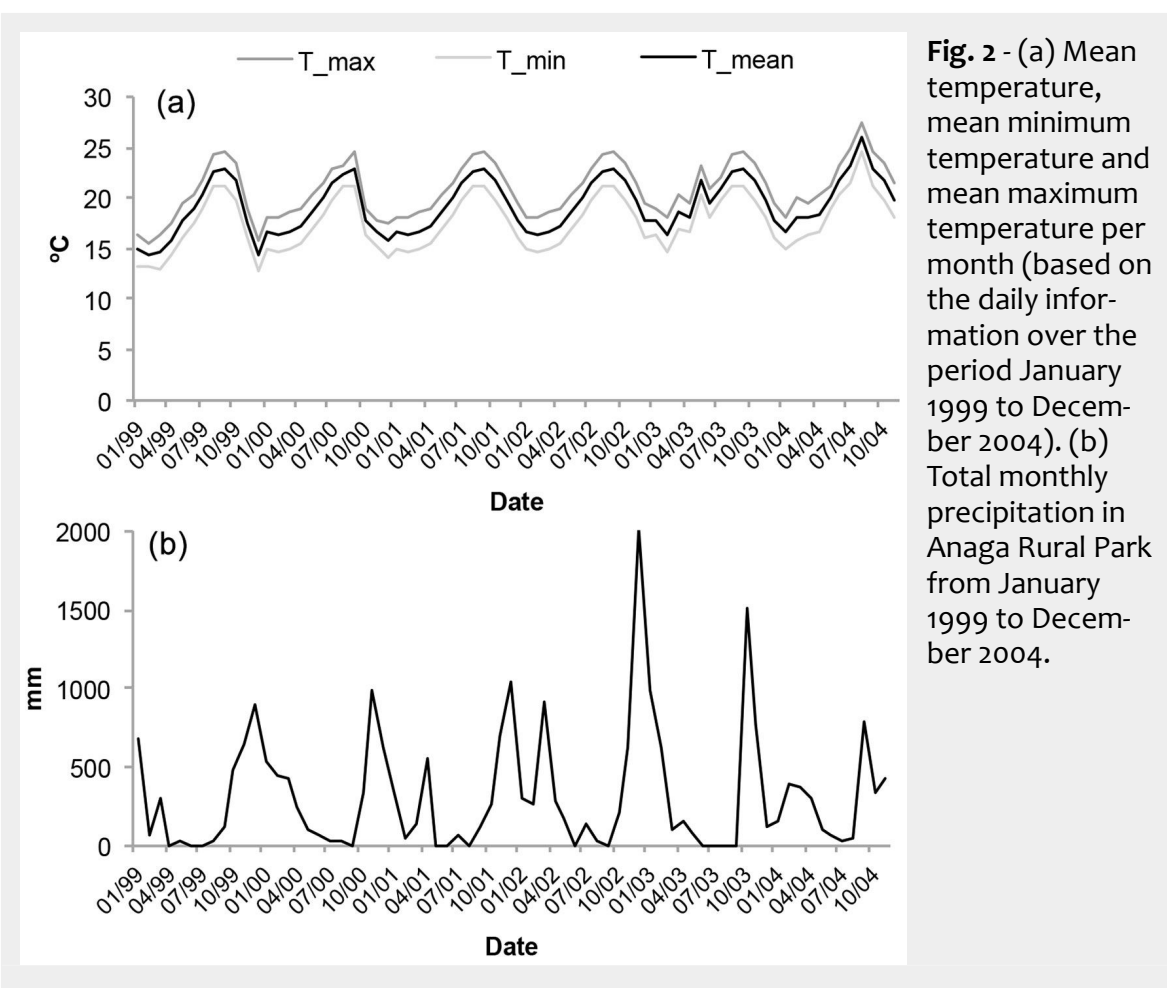




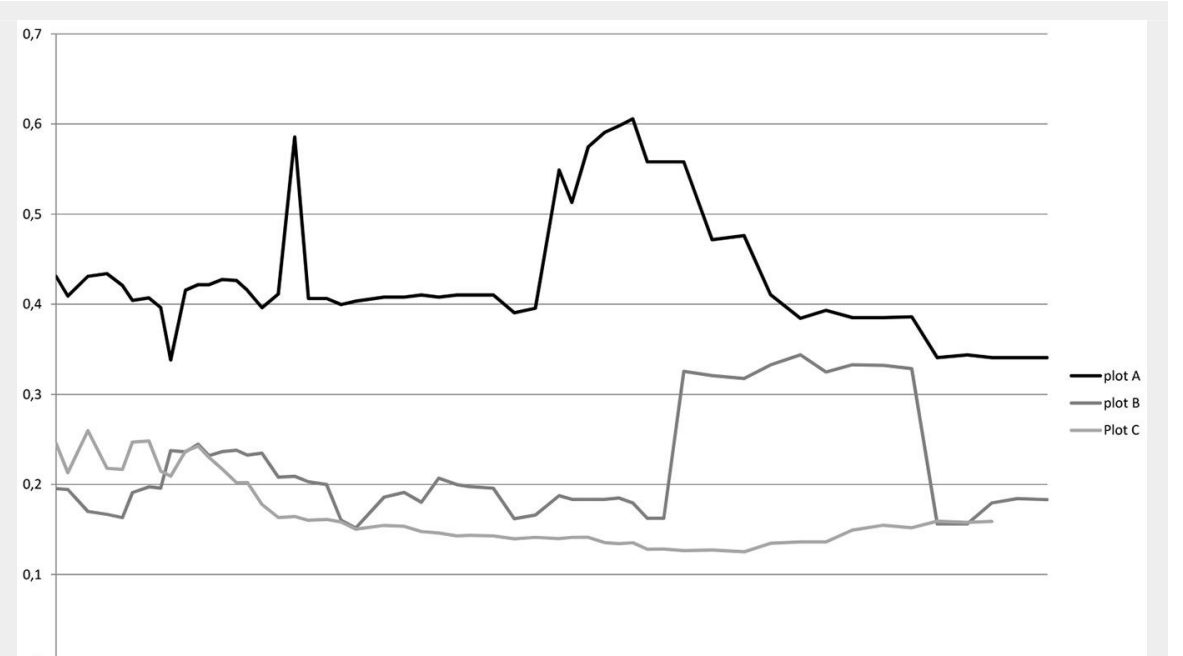

October-November, although winter periods also have some important precipitation (Fig. 2b). November 2002 was particularly intense in rains, as was November 2003 , while the rest of the years the precipitation remained regular (900-1000 mm).

Environmental variables (Tab. 1) did not reveal significant differences and neither did other stand structure variables analysed (density, basal area and species richness - $p>0.05$ ). Altitude ranged between 685 and $900 \mathrm{~m}$ a.s.l., well within the laurel forest elevational belt. Tree density was variable, between 1300 to 4900 ind. ha ${ }^{-1}$ (26\% variation), while basal area showed a variation among plots of almost 55\% (32.02 to $58.92 \mathrm{~m}^{2} \mathrm{ha}^{-1}$ ), pointing to a certain difference in the maturity of the plots. A total of 15 tree species were found in the study, three of them (Ocotea foetens, Rhamnus glandulosa and Visnea mocanera) being absent from the plot canopies and three more (Erica arborea, E. platycodon ssp. platycodon and Morella faya) absent from the seedling banks.

Results of the evenness analysis for the 9 plots (Fig. 3) showed the highest values for plot $\mathrm{H}$, with more than $50 \%$ of variability over the three years, and reaching in some cases values of 1 (for a period at the end of 2002), while the other plots ( $G$ and $J$ ) of the same area ("Monte de Aguirre") remained constant throughout the three years with low values, between 0.15 and 0.3. In the group of plots A, B and C ("El Moquinal"), plot $A$ had values over 0.4 increasing for a period to 0.6 , while plots $B$ and $C$ remained, in general, constant between 0.1 and 0.35 . Finally, plots D, E, F ("Barranco de los Núñez") had a more constant variation, starting at values of 0.5 but decreasing over the three years to 0.1 in the case of plot $F$ and to 0.25 in plot $D$.

The ordination analysis (Fig. 4) revealed that only plots $C$ and $J$ had some consistency between the seedling bank and the canopy composition: these plots were located near the centroids of the regeneration plots (Plot A, Plot B, Plot C, Plot D, Plot_E, Plot_F, Plot_H). The rest of the canopy plots (Can_A, Can_D, Can_F, Can_G, Can_H) had pioneer species such as Erica arborea, E. platycodon ssp. platycodon, and Morella faya, but also some mid to late successional species such as Ilex canariensis, I. perado ssp. platyphylla, Prunus lusitanica ssp. hixa and Heberdenia excelsa, as the representative species of the canopy composition. However, the seedling bank composition was characterized by Laurus novocanariensis, Picconia excelsa, Persea indica, Ocotea foetens, and Rhamnus glandulosa, mesic species of well-preserved laurel forest stands (Arévalo 1998). Some canopy plots were located at a more intermediate position (Can_B and Can_E). There was a gradient of species composition along Axis I from seedling plots to canopy plots. In the case of Axis II, seedling bank of Plot $G$ was discriminated due to the occurrence of Apollonias barbujana, Viburnum rigidum 
and Visnea mocanera. This plot was characterized by a high tree density and a lower elevation with respect to the others (Tab. 1).

\section{Discussion}

During three years of sexual regeneration monitoring in the laurel forest of Anaga, we found 15 tree species, of which 11 appeared as canopy trees (all except Heberdenia excelsa, Ocotea foetens, Rhamnus glandulosa and Visnea mocanera), while 12 appeared in the seedling banks (all except Erica arborea, E. platycodon ssp. platycodon and Morella faya). The first group of species absent in the plot canopies are non-pioneer species, some of them are considered as very specific to certain environments, such as $\mathrm{V}$. mocanera or $\mathrm{H}$. excelsa for the xeric laurel forest (Arévalo 1998), while $O$. foetens prefers the most humid parts of the forest (Del Arco et al. 2006). Their absence from the canopy within the studied area ( $900 \mathrm{~m}^{2}$ in total) might be explained by their specificity to certain environments and does not imply they are not present in nearby areas. This means that tree species richness would be better captured by larger sampling areas within the laurel forest, for instance $50 \times 50 \mathrm{~m}$ plots (Arévalo et al. 1999, 2012). Regarding the species absence from the seedling banks, they correspond to the three pioneer species occurring in the laurel forest (Fernández-Palacios \& Arévalo 1998). This is a common situation found in previous studies in this forest, in which human activities (wood extraction, agriculture, charcoal production, etc.) have promoted the occurrence of pioneer species in the forest. However, seeds from these pioneer species only germinate under light conditions, so they cannot be found under a closed canopy (FernándezPalacios \& Arévalo 1998). Therefore, the adult trees of these species are just remnants of the early successional stages of the forest. These trees may persist within the forest for decades; in particular, $M$. faya is able to regenerate vegetatively by producing basal sprouts, and the trees are usually among the biggest and oldest in the laurel forest (Fernández \& GomézGonzález 2016). After several decades of strict conservation of the Anaga Rural Park, the canopy composition cannot be explained based on the sexual regeneration. Pioneer species are now more abundant in other communities like the fayalbrezal (Morella-Erica woody heath - Arévalo et al. 1999), and are clearly present in the laurel forest seed bank but are unable to germinate (Arévalo \& Fernández-Palacios 1998).

In this study, environmental conditions did not significantly differ among the plots within the same stand. However, aspect is an important determinant of species composition (Arévalo et al. 2012, Ohsawa et al. 1999) which is supposed to control species richness or basal area and density. Nonetheless, we did not find any significant dif-

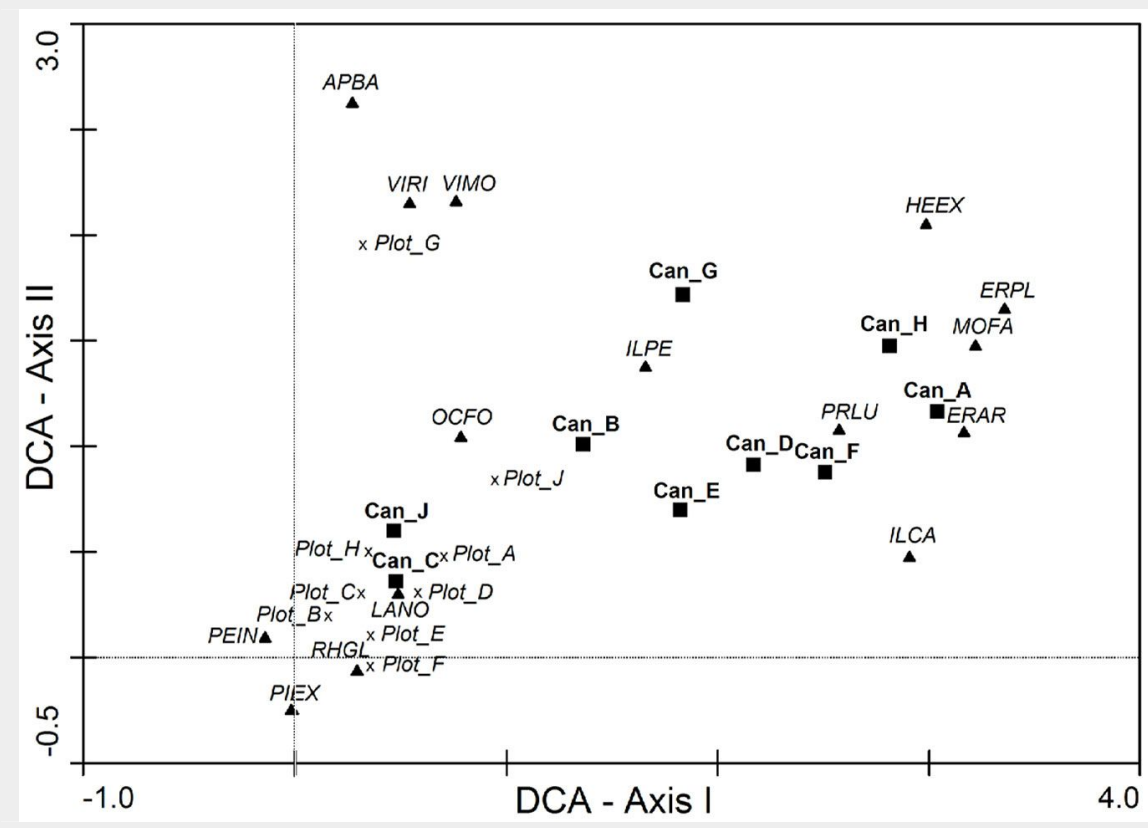

Fig. 4 - Detrended Correspondence Analysis (DCA) of the regeneration (seedling bank) plots and canopy (tree) plots with the species composition based in percentage abundance. Regeneration plot coordinates indicate the centroid of all the sampled periods with a cross (Plot_A, Plot_B, Plot_C, ..., Plot_J), canopy plots are represented with a black square (Can $A$, Can $B$, Can $-\mathcal{C}, \ldots$, Can $\bar{J}$ ), and the species coordinates is represented with a triangle with the names indicated by the two first letters of their genus followed by the first two letters of the species: Apollonias barbujana (APBA), Erica arborea (ERAR), Erica platycodon ssp. platycodon (ERPL), Heberdenia excelsa (HEEX), llex canariensis (ILCA), Ilex perado ssp, platyphylla (ILPE), Laurus novocanariensis (LANO), Morella faya (MOFA), Ocotea foetens (OCFO), Persea indica (PEIN), Picconia excelsa (PIEX), Prunus lusitanica ssp. hixa (PRLU), Rhamnus glandulosa (RHGL), Viburnum rigidum (VIRI) and Visnea mocanera (VIMO). Eigenvalue for axis I: 0.639, eigenvalue for axis II: 0.532 , cumulative percentage of variance of species data for axes I and II: $41.6 \%$.

ference among stands in terms of species richness, basal area and density. According to these results, local environmental differences seem to be more relevant than those of the stand or even the aspect of the plot. The evenness index revealed differences among groups of plots, confirming that microenvironmental conditions are an important issue in determining species germination (Fernández-Palacios \& Arévalo 1998). It is worth noting that while some plots remain constant in their seedling species composition over the period regardless of the weather conditions, some others showed more variability, although this was hardly related with climate (Fig. 2 ). In this case, we assumed that the environmental conditions were equally suitable for all the species (being all typical of the laurel forest) and equally affect the seedling bank community.

The distribution of seedlings in the forest is dependent on the distribution of parent trees producing seeds, the seed rain, the presence of dispersers and predators and the availability of adequate sites for germination (Schupp 1995). Based on the lack of relationships between the seedling bank composition and the tree composition in some plots, the role of dispersers becomes essential to understand these results. In previous studies, the importance of dispersers, mainly birds, in the spreading of fruits has been shown (Valido \& Delgado 1996, Arteaga et al. 2006, Arévalo et al. 2007). However, the environmental pressure in this ecosystem is not so strong as to create a completely dependent relationship of fruit dispersers. Moreover, the fruit production does not differ between species (Arévalo et al. 2007). Some of the plots (such as plot $J$ and $C$ ) are more similar in their canopy species composition and their seedlings than other plots, and even more similar to the seedling bank of the other plots than their own ones (as in the case of plot J). This lack of relationship between species composition of canopy and seedling bank has been previously analysed by models, which predicted a change in the laurel forest canopy in Anaga, with an increase of later successional species (e.g., Lauraceae) and a reduction of pioneer ones (such as Erica arborea, E. platycodon ssp. platycodon and Morella faya). Given the low climate variability and low disturbance regime, shade intolerant species are expected to be displaced to marginal areas in the forest or even to areas affected by anthropogenic disturbance, as long as natural disturbances do not foster the establishment of these pioneer species within 
the forest (Arévalo \& Fernández-Palacios 1998, 2000, 2007).

Although sexual regeneration of shadeintolerant species has not been recorded in the period analysed, there is evidence that they are present in the seed bank over the whole area of the laurel forest in Anaga (Arévalo \& Fernández-Palacios 2007). Similar situations have been reported by other studies concerning seed bank analysis (Thompson 1992). Furthermore, some of the early successional species can reproduce mainly by asexual regeneration, thus ensuring their presence in the stand for many generations; therefore, although changes in species composition are expected, these are assumed to be long term. Finally, to fully understand species composition in the laurel forest at the present time, the human intervention has to be considered, as the arrival of Europeans in the Canary Islands five centuries ago had an important impact on the extension of this forest (Parsons 1981).

In summary, the enhanced conservation measures applied to the laurel forest of Anaga (by closing unpaved roads, limiting access, and the abandonment of agriculture) had negatively affected the density of shade-intolerant species. We recommend such conservation measures to be maintained and extended to other areas where agriculture has been recently abandoned, in order to allow the establishment of potential laurel forest and late successional species, thus providing better opportunities for the recovery of this plant community.

\section{Acknowledgments}

We thank the Rolle-Stiftung and Hotel Océano for their economic support. We are also grateful to the staff of Anaga Rural Park for granting permission to conduct this study and their support for the project. Climatic data were provided by the Agencia Estatal de Meteorología (AEMET). We are also grateful to all the field-work assistants: Cristina Blandino, Alistair Dominguez, Gustavo Morales and Priscila Rodríguez. We also appreciate the comments and corrections on the English provided by Clive Tyrell, professional technical editor.

\section{References}

Acebes JR, León MC, Rodríguez ML, Arco M, García A, Pérez PL, Wildpret De La Torre W, Martín Osorio VE, Marrero Gómez MC, Rodríguez Navarro ML (2010). Pteridophyta, Spermatophyta. In: "Lista de especies silvestres de Canarias (hongos, plantas y animales terrestres" [Check list of wild species of the Canary Islands: fungus, plants and terrestrial animals] (Arechavaleta $M$, Rodríguez $\mathrm{S}$, Zurita $\mathrm{N}$, García A eds). Gobierno de Canarias, $\mathrm{S} / \mathrm{C}$ de Tenerife, Spain, pp. 119-172. [in Spanish]

Ancochea E, Fúster JM, Ibarrola E, Cendrero A, Coello J, Hernán F, Cantagrel JM, Jamond C (1990). Volcanic evolution of the island of Tenerife (Canary Islands) in the light of new K-AR data. Journal of Volcanology and Geothermal
Research 44: 231-249. - doi: 10.1016/0377-0273 (90)90019-C

Arteaga MA, González G, Delgado JD, Arévalo JR, Fernández-Palacios JM (2006). Offspring spatial patterns in Picconia excelsa (Oleaceae) in the Canarian laurel forest. Flora 201: 642-651. - doi: 10.1016/j.flora.2006.01.001

Arévalo JR (1998). Distribución espacial y temporal de la laurisilva de Anaga, Tenerife. Islas Canarias [Spatial and temporal distribution of the laurel forest of Anaga, Tenerife. Canary Islands]. PhD Thesis, Universidad de La Laguna, La Laguna, Spain, pp. 110. [in Spanish]

Arévalo JR, Fernández-Palacios JM (1998). Treefall gap characteristics and its influence on regeneration in the laurel forest of Tenerife (Canary Islands). Journal of Vegetation Science 9: 297-306. - doi: 10.2307/3237094

Arévalo JR, Fernández-Palacios JM, Palmer M (1999). Tree regeneration and predicted future dynamics in a laurel forest (Tenerife, Canary Islands). Journal of Vegetation Science 10: 861868. - doi: 10.2307/3237311

Arévalo JR, Fernández-Palacios JM (2000). Seed bank analysis of tree species in two stands of the Tenerife laurel forest (Canary Islands). Forest Ecology and Management 130: 177-185. doi: 10.1016/S0378-1127(99)00182-6

Arévalo JR, Delgado JD, Fernández-Palacios JM (2007). Variation in fleshy fruit fall composition in an island laurel forest of the Canary Islands. Acta Oecologica 32: 152-160. - doi: 10.1016/j.acta 0.2007 .03 .014

Arévalo JR, Fernández-Palacios JM (2007). Treefall gaps and regeneration composition in the laurel forest of Anaga (Tenerife): a matter of size? Plant Ecology 188: 133-143. - doi: 10.1007/ s11258-006-9152-1

Arévalo JR, Gónzalez-Delgado G, Mora B, Fernández-Palacios JM (2012). Compositional and structural differences in two laurel forest stands (windward and leeward) on Tenerife, Canary Islands. Journal of Forest Research 17: 184-192. - doi: 10.1007/s10310-011-0293-2

Ceccon E, Huante P, Rincón E (2006). Abiotic factors influencing tropical dry forests regeneration. Brazilian Archives of Biology and Technology 49: 305-312. - doi: 10.1590/S1516-891320060 00300016

Del Arco MJ, Wildpret W, Pérez de Paz PL, Rodríguez O, Acebes JR, García A, Martín VE, Reyes JA, Salas M, Díaz MA, Bermejo JA, González R, Cabrera MV, García S (2006). Mapa de Vegetación de Canarias [Vegetation Map of the Canary Islands]. GRAFCAN, Santa Cruz de Tenerife, Spain, pp. 552. [in Spanish]

Del Arco M, González-González R, Garzón-Machado V, Pizarro-Hernández B (2010). Actual and potential natural vegetation on the Canary Islands and its conservation status. Biodiversity and Conservation 19: 3089-3140. - doi: 10.1007/ s10531-010-9881-2

Fernández AB, Goméz-González L (2016). Qué son los bosques antiguos de laurisilva. Su valor y situación en Canarias [What are the old laurel forest. Value and status in the Canary Islands]. In: "La Gomera entre bosques y taparuchas" [La Gomera between forests and "taparuchas"] (Afonso J ed). Instituto de Estudios Hispánicos de Canarias, Puerto de La Cruz, pp. 1-60. [in Spanish]
Fernández Caldas E, Tejedor M, Quantin P (1985). Los suelos volcánicos de Canarias [Volcanic soils of the Canary Islands]. Servicio de Publicaciones Universidad de La Laguna, Santa Cruz de Tenerife, Spain, pp. 248. [in Spanish]

Fernández-Lugo S, De Nascimento L, Méndez J, González-Delgado G, Gomes EPC, Otto R, Arévalo JR, Fernández-Palacios JM (2015). Seedling survival patterns in the laurel forest: a longterm study in Tenerife (Canary Islands). Forestry 88: 121-130. - doi: 10.1093/forestry/cpu035 Fernández-Palacios JM, Arévalo JR (1998). Regeneration strategies of tree species in the laurel forest of Tenerife. Plant Ecology 137: 21-29. doi: 10.1023/A:1008000330184

Fernández-Palacios JM (2009). (9360) Laurisilvas macaronésicas (Laurus, Ocotea) [Macaronesian laurel forests]. In: "Bases ecológicas preliminares para la conservación de los tipos de hábitat de interés comunitario en España" [Ecological premises for conservation of habitats of interest in the European Community]. Ministerio de Medio Ambiente y Medio Rural y Marino, Madrid, Spain, pp. 68. [in Spanish]

Franklin J, Drake D, Bolick L, Smith D, Motley T (1999). Rain forest composition and patterns of secondary succession in the Vava'u Island Group, Tonga. Journal of Vegetation Science 10: 51-64. - doi: $10.2307 / 3237160$

García D (2001). Effects of seed dispersal on Juniperus recruitment on a Mediterranean mountain. Journal of Vegetation Sciences 12: 839848. - doi: $10.2307 / 3236872$

Gauch H (1982). Multivariate analysis in community ecology. Cambridge University Press, Cambridge, UK, pp. 298. - doi: 10.1017/CBO97805116 23332

Hamilton LS, Juvik JO, Scatena FN (1995). The Puerto Rico tropical cloud forest symposium: Introduction and workshop synthesis. Ecological Studies 110: 1-23. - doi: 10.1007/978-1-46122500-3_1

Hill M, Gauch H (1980). Detrended correspondence analysis, an improved ordination technique. Vegetatio 42: 47-58. - doi: 10.1007/BFooo 48870

Kämmer F (1974). Klima und vegetation auf Teneriffa, besonders im Hinblick auf den Nebelniederschalg [Climate and vegetation of Tenerife, with special regard to the fog effect]. Scripta Geobotanica 78, Göttingen, Germany, pp. 19. [in German]

Kitajima K (2007). Seed and seedling ecology. In: "Functional Plant Ecology" (Pugnaire, Jl, Valladares $\mathrm{F}$ eds). CRC Press, Boca Ratón, FL, USA, pp. 549-579.

Morales G, Pérez R (2000). Gran atlas temático de Canarias [Great thematic atlas of the Canary Islands]. Editorial Interinsular Canaria, Santa Cruz de Tenerife, Spain, pp. 376. [in Spanish]

Ohsawa M, Shumiya T, Nitta I, Wildpret W, Del Arco M, Reyes-Betancort A (1999). Structure and differentiation of cloud forest along topographical gradients in Anaga mountains, Tenerife, The Canary Islands. In: "A comparative study on evergreen broad-leaved forest and trees of the Canary Islands and Japan" (Ohsawa M, Wildprett W, Del Arco M eds). Chiba University, Chiba, Japan, pp. 67-118.

Parsons JJ (1981). Human influence in the pine and laurel forest of the Canary Islands. Geo- 
graphical Review 71: 253-271. - doi: 10.2307/21 4699

Peterken GF (1996). Natural woodland: ecology and conservation in northern temperate regions. Cambridge University Press, Cambridge, UK, pp. 522. [online] URL: http://books. google.com/books?id=p3y43NnvXPYC

Rey PJ, Alcántara JM (2000). Recruitment dynamics of a plant (Olea europaea): connecting patterns of seed dispersal to seedling establishment. Journal of Ecology 88: 622-633. - doi: 10.1046/j.1365-2745.2000.00472.x

Santos A (1990). Bosques de laurisilva en la región macaronésica [Laurel forests of the Macaronesian Region]. Colección Naturaleza y Medio ambiente 49, Council of Europe, Strasbourg, France, pp. 77. [in Spanish]

Schupp EW (1995). Seed-seedling conflicts, habitat choice and patterns of plant recruitment. American Journal of Botany 82: 399-409. - doi: 10.1002/j.1537-2197.1995.tb12645.x

Shono K, Cadaweng EA, Durst PB (2007). Appli- cation of assisted natural regeneration to restore degraded tropical forestlands. Restoration Ecology 15: 620-626. - doi: 10.1111/j.1526100X.2007.00274.x

Smith B, Wilson JB (1996). A consumer's guide to evenness indices. Oikos 76: 70-82. [online] URL: http://www.jstor.org/stable/3545749

Smith DM, Larson BC, Kelty MJ, Ashton PM (1997). The practice of silviculture ( $9^{\text {th }}$ edn). Applied Forest Ecology, John Wiley and Sons Inc., New York, USA, pp. 537.

SPSS Inc (1997). SPSS base 7.5 for Windows. User's Guide. SPSS Chicago, IL, USA.

Ter Braak CJF, Šmilauer P (1998). CANOCO. Reference manual and user's guide to Canoco for Windows: software for canonical community ordination ( $4^{\text {th }}$ version). Microcomputer Power, Ithaca, NY, USA, pp. 500.

Tesfaye G, Teketay D, Fetene M (2002). Regeneration of fourteen tree species in Harenna forest, southern Ethiopia. Flora 197: 461-467. - doi: 10.1078/0367-2530-1210063
Thompson K (1992). The functional ecology of the seed banks. In: "The ecology of regeneration in plant communities" (Fenner $M$ ed). CAB International, Wallingford Oxon, UK, pp. 231257.

Valido A, Delgado JD (1996). Estudio sobre la comunidad de aves de la laurisilva de la isla de Tenerife (Islas Canarias) [Study of the laurel forest bird community at the island of Tenerife (Canary Islands)]. Seo-Birdlife, Viceconsejería de Política Territorial del Gobierno de Canarias, Santa Cruz de Tenerife, Spain, pp. 167. [in Spanish]

Vieira DLM, Scariot A (2006). Principles of natural regeneration of tropical dry forests for restoration. Restoration Ecology 14: 11-20. - doi: 10.1111/j.1526-100X.2006.00100.x

Zar JH (1984). Biostatistical analysis ( $2^{\text {nd }}$ edn). Prentice-Hall, Englewood Cliffs, NJ, USA, pp. 718. 